\title{
Elevated natural As in surface water around the Guallatiri volcano, northern Chile
}

\author{
M. INOSTROZA ${ }^{1,2^{*}}$, F. AGUILERA ${ }^{1,2,3}$, J. TAPIA $^{3,4}, \mathrm{~J}$. \\ SEPÚLVEDA $^{2,5}$, F. TASSI $^{5}$
}

${ }^{1}$ Programa de Doctorado en Ciencias, mención Geología, UCN (manuel.inostroza@alumnos.ucn.cl)

${ }^{2}$ Núcleo de Investigación en Riesgo Volcánico - Ckelar Volcanes, UCN.

${ }^{3}$ Departamento de Ciencias Geológicas, UCN

${ }^{4}$ IGCP-707 UNESCO

${ }^{5}$ Dipartimento di Scienze della Terra, Università di Firenze

Guallatiri $\left(18^{\circ} 25^{\prime} \mathrm{S}, 69^{\circ} 05^{\prime} \mathrm{W}\right.$; $6073 \mathrm{~m}$ a.s.l.) is a giant and active stratovolcano located in northern Chile, near the Chile-Bolivia border. On the top and SW flank, it presents hundreds of fumarolic emissions. The summit area hosts a permanent glaciar cap that feeds the hydrothermal system of the volcano as well as cold/thermal springs emerging at the base of the volcanic edifice.

This work reports As concentration, analyzed by ICPOES, in rivers (Caullatiti, Patuias, and Captalia) and thermal springs (Chirigualla) located around Guallatiri volcano, and water vapor from the volcanic fumaroles, with the aim to evaluate the quality of water used by local inhabitants for irrigation, drinking and cooking purposes.

Arsenic concentrations in fumarolic vapors ranged from 3.7 to $6.3 \mathrm{mg} \cdot \mathrm{L}^{-1}$, whereas in Chirigualla thermal springs they were up to $4.8 \mathrm{mg} \cdot \mathrm{L}^{-1}$. By comparison, water samples from Captalia, Caullatiri and Patuias rivers, reached As concentrations of $0.17,0.048$ and $0.047 \mathrm{mg} \cdot \mathrm{L}^{-1}$, respectively.

The Captalia river was found to be the most affected by As contamination, although Caullatiri and Patuias show also high As values that exceed the limit value for drinkable water $\left(0.01 \mathrm{mg} \cdot \mathrm{L}^{-1}\right.$ according the World Health Organization) by a factor of 17 and $\sim 5$, respectively. Concentration of As in running and thermal waters is consistent with those found in diluited volcanic-geothermal waters, whereas significative amounts of $\mathrm{Li}$ (up to $1.8 \mathrm{mg} \cdot \mathrm{L}^{-1}$ ) and $\mathrm{B}$ (up to $18 \mathrm{mg} \cdot \mathrm{L}^{-1}$ ), and relatively low $\mathrm{Cl} / \mathrm{B}$ ratios $(\sim 18)$ allow to relate these surface waters to a volcanic source, in this case with the hydrothermal system of the Guallatiri volcano.

A detailed study of the distribution and concentration of As in the surroundings of the Guallatiri volcano should be carried out in order to identify risks to the nearby population. 